\title{
Inflation Targeting Under Imperfect Policy Credibility
}

Ali Alichi, Huigang Chen, Kevin Clinton, Charles Freedman, Marianne Johnson, Ondra Kamenik, Turgut Kişınbay, and Douglas Laxton 



\title{
IMF Working Paper
}

\author{
Research Department
}

\section{Inflation Targeting Under Imperfect Policy Credibility}

\author{
Prepared by Ali Alichi, Huigang Chen, Kevin Clinton, Charles Freedman, \\ Marianne Johnson, Ondra Kamenik, Turgut Kışınbay, and Douglas Laxton ${ }^{1}$
}

Authorized for distribution by Charles Collyns

April 2009

\begin{abstract}

\section{This Working Paper should not be reported as representing the views of the IMF.} The views expressed in this Working Paper are those of the author(s) and do not necessarily represent those of the IMF or IMF policy. Working Papers describe research in progress by the author(s) and are published to elicit comments and to further debate.

This paper presents a model for Inflation Targeting under imperfect policy credibility. It modifies the conventional model in three ways: an endogenous policy credibility process, by which monetary policy can gain or lose credibility over time; non-linearities in the inflation equation and in the credibility generating process; and an explicit loss function. The model highlights problems associated with the practice of setting a series of rigid near-term inflation targets. Also, unfavorable supply shocks pose a difficult problem: an appropriate response involves an interest rate increase, some loss of output, and a period of increased inflation. A delayed response can result in a prolonged period of stagflation.
\end{abstract}

JEL Classification Numbers: C51; E31; E52

Keywords: monetary policy, credibility, disinflation

Author's E-Mail Address: dlaxton@imf.org, aalichi@imf.org, okamenik@imf.org, tkisinbay@imf.org, mjohnson@bankofcanada.ca

\footnotetext{
${ }^{1}$ C. Freedman is Scholar in Residence in the Economics Department, Carleton University, Ottawa, Canada and Marianne Johnson is a Research Advisor at the Bank of Canada. The views expressed in this paper are those of the authors and do not necessarily represent those of the IMF or IMF policy. We thank Andy Berg, Charles Collyns, Marshall Mills, Piroshka Nagy, and several participants at various seminars for providing comments and for encouraging us to do this work. The code for the model simulations used in this paper can be downloaded fromwww.douglaslaxton.org
} 


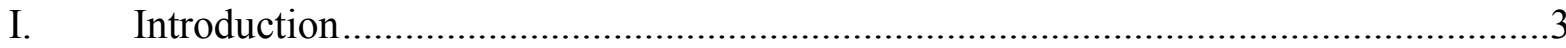

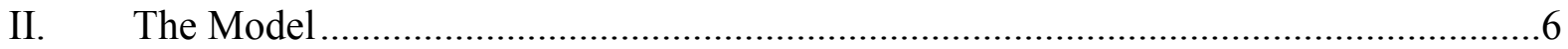

A. Inflation Process with Endogenous Credibility ...............................................

A.1 Inflation equation-an expectations-augmented Phillips curve .....................

A.2 Output Gap equation ............................................................................. 10

A.3 Exchange rate-real interest rate parity equation .......................................11

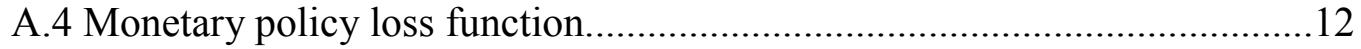

A.5 Note on calibration............................................................................ 13

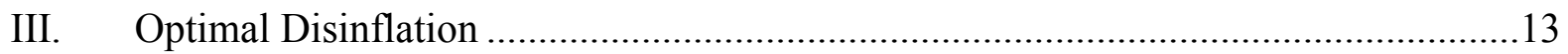

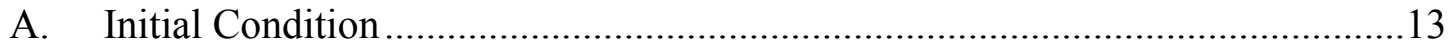

B. Disinflation Under Various Degrees of Credibility ........................................14

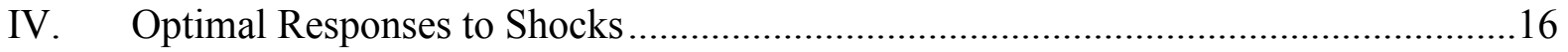

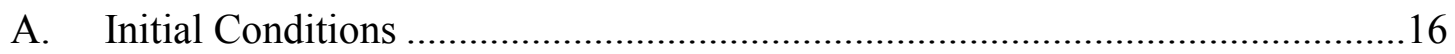

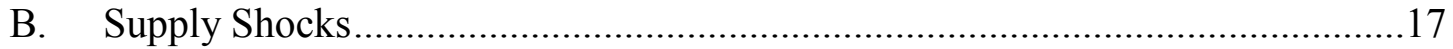

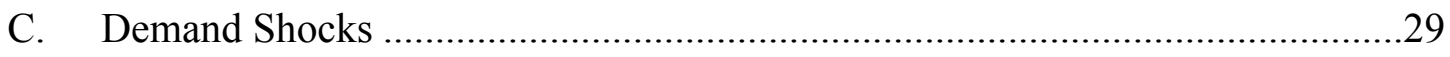

V. Costs of Delaying Interest Rate Increase Under Imperfect Credibility .....................20

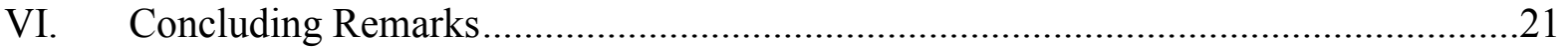

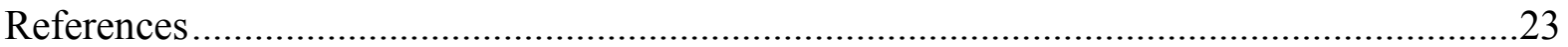

Figures

1. Disinflation with Equal Weights on Inflation, Output and Interest Rate Variability............................................................................26

2. Disinflation with Lower Weights on Output and Interest Rate Variability ................27

3. Responses to Unfavorable and Favorable Supply Shocks (Positive Shock

Circle; Negative Shock Triangle) ..............................................................28

4. Responses to Positive and Negative Demand Shocks (Positive Shock Circle

Negative Shock Triangle...........................................................................29

5. Cost of Delaying Interest Rate Hikes in Response to an Unfavorable Supply

Shock in an Economy with High Inflation and Low Initial Credibility

(No Delay Triangle; Delay Circle) 


\section{Introduction}

There have been two set of circumstances in which countries have adopted inflation targeting (IT). The first pertains to countries that have already achieved their desired rate of inflation and see IT as a way of maintaining that rate. The second pertains to countries, mainly emerging-market economies, in which the rate of inflation is significantly above their long-term inflation objective and which adopt an IT regime as a way of bringing about a reduction in inflation to their long-term inflation goal. ${ }^{2}$ The level of credibility is typically much higher in the former case than in the latter case. This paper focuses on the relationship between the level of credibility and the optimal monetary policy to achieve or maintain the long-run target for inflation. It also compares the appropriate response to supply and demand shocks in circumstances of high and low policy credibility.

Typically, countries using IT as their framework for disinflation have put heavy emphasis on achieving reductions in the inflation rate every year, often with an explicit pre-announced target schedule, as a way of establishing the central bank's commitment to price stability. In some countries, such as Canada, a medium-term target path for inflation (from 1991 to 1995) was set out in the initial announcement of IT. In other countries, such as Israel, the authorities announced the disinflation path one year at a time. But, in both cases, the disinflation path towards the equilibrium long-term rate of inflation was treated as a formal target or set of targets. Another notable characteristic of the IT framework over the disinflation period was that central banks took stronger policy actions in response to unfavorable supply shocks than in response to favorable supply shocks. This was in contrast to their reaction to positive and negative demand shocks, which was more symmetrical.

In practice, inflation frequently fell outside the announced target range during the disinflation period. Roger and Stone (2005, Table 7) found that the frequency of outcomes outside the range for countries with disinflation targets was 60 percent, divided almost equally between overshoots and undershoots. Moreover, viewed in retrospect, monetary policy in several cases responded too vigorously to these deviations in an attempt to get inflation quickly back on target and to maintain its credibility, and such actions resulted in excessive variability in the economy. The overly aggressive focus on hitting short-run targets could also have effects stretching beyond their intended short-run purpose, pushing the inflation rate to the other side of the target range, and requiring strong reverse actions. Over time, it has become clear that it is not optimal to keep inflation within a narrow target range each and every year regardless of circumstances.

In some cases, disinflating central banks had problems in communicating their policy objectives. Because of concerns with credibility, they explained their framework and policy actions almost solely on the basis of achieving the target rate of inflation. One of the

\footnotetext{
${ }^{2}$ Examples of countries that have introduced inflation targeting with the goal of reducing inflation are Brazil, Canada, Chile, Colombia, Czech Republic, Hungary, Israel, Korea, Mexico, New Zealand, Peru, and Poland (Mishkin and Schmidt-Hebbel, 2001, Table 2).
} 
objectives of a central bank in an IT framework, along with achieving the desired decline in the rate of inflation, is to limit output variability, as shown in the Svensson (1997) type of central bank loss function that contains as arguments both the deviation of inflation from target and the deviation of output from potential. A central bank can improve its policy actions and strengthen its credibility by clearly communicating that its policy is about more than hitting annual targets, that its actions involve short-run trade-offs, and that it is mindful of undesired effects on output and employment. As experience has been gained with the IT framework, policymakers have become clearer that their policy approach is one of flexible inflation targeting, and that they accord great importance to accountability and to transparency in communications. ${ }^{3}$

Along the disinflation path central banks have to address a number of questions. These include: (1) Should the authorities announce intermediate targets for the next few years and the long-term target, or only intermediate targets for the next few years, or only the long-term target? (2) What is an appropriate pace of inflation reduction? (3) How should monetary policy respond to unexpected events on the disinflation path, most importantly unfavorable supply shocks? (4) What sort of flexibility is appropriate in the execution of policy?

In this paper, we examine some of the issues related to disinflation under IT in an emerging-market economy using a model with endogenous, imperfect credibility and various nonlinearities. This model is an adaptation of the work-horse model used at many central banks. It has equations for the inflation rate, the output gap, and the real exchange rate, and it uses a monetary policy loss function in place of the more common Taylor-type rule.

Models of this kind have been found useful for assessing the implications of different shocks and strategic options, and for communicating the rationale of policy decisions to the public in a consistent framework. Recent practice has been to calibrate the parameters, using a broad range of relevant evidence, rather than to rely on classical estimation techniques. This is very convenient in the context of emerging-market economies, where time-series data are not abundant. ${ }^{4}$

Our model contains three novel features relevant to a policy of inflation reduction: ${ }^{5}$

\footnotetext{
${ }^{3}$ One of the recent advances in transparency has involved the publication of an endogenous interest rate forecast path by a number of inflation targeting central banks - the Reserve Bank of New Zealand; the Norges Bank; the Riksbank; and the Czech National Bank. Lars Svensson and Michael Woodford have been prominent advocates of publishing the central bank's forecast of the policy rate, e.g., Woodford (2005). Some recent evidence based on the Norges Bank experience suggests that monetary policy has become more predictable in the sense that there are now smaller revisions in 1-year market rates following the release of the Norges Bank Inflation Reports - see Freedman, Laxton and Ötker-Robe (2008).

${ }^{4}$ In several cases, models developed to support IT regimes have been calibrated because of significant data issues or structural change that made past empirical relationships poor guides for the future. Over time, as more data became available there has been a tendency to employ Bayesian methods to estimate macro models.

${ }^{5}$ The model used in this paper belongs to the family of models found in Laxton and N'Diaye (2002), Isard, Laxton, Eliasson (2001), and Argov, Epstein, Karam, Laxton and Rose (2007).
} 
- an endogenous credibility process - starting from a situation in which people expect inflation to remain high, policymakers may build credibility over time, such that public expectations of inflation converge to the target rate, or lose credibility as the public begins to doubt their commitment to achieving low inflation;

- a number of nonlinearities, most importantly in the specification of the output gap and in the specification of the process by which credibility changes; and

- as noted, a loss function for monetary policy that recognizes the costs of deviations of inflation from target and output from potential as well as fluctuations in interest rates, in place of a conventional reaction function for the policy interest rate.

The ultimate stable low-inflation objective is the nominal anchor for the model and provides the foundation for improved expectations and credibility. The disinflation path is endogenous and depends on the level of credibility at the time that the inflation-reduction program is adopted, as well as on other initial conditions. The loss-minimizing path to the low-inflation goal is more gradual than it would be if policy were 100 percent credible at the outset. Building credibility takes time and the central bank has to produce ongoing declines in inflation to convince a skeptical public that it does intend to achieve the target that it announced. However, if the central bank chooses an overly short horizon for reaching the final inflation target, the usual adjustment lags in spending and price setting imply greater losses in the loss function than in a more gradual disinflation path.

In this paper, we derive a smooth (but not linear) path for inflation reduction given the starting position. We investigate the implications of various initial conditions and shocks, and alternative policy options. One of the results is that in certain circumstances the policy program requires an appreciable interest rate hike initially, and putting off the increase only means a larger increase later. The model results also indicate the advantage of announcing a long-run inflation target and presenting the intermediate path as a conditional forecast rather than as a series of interim targets.

While initial conditions can affect the desired path for disinflation at the time of the announcement of IT, shocks along that path can also have an important effect on the eventual optimal path. Model simulations suggest that supply shocks can have an especially large impact on the desirable rate of disinflation. A favorable supply shock, which reduces inflation, can help monetary policy, boosting credibility and reducing the necessary interest rate increase, as well as shortening the path to the long-run objective. A harmful supply shock - e.g., an increase in world food or energy prices - presents, in contrast, the most difficult problem for inflation control. Large interest rate increases may be needed to prevent a self-propagating inflation spiral. In such situations, a delay in tightening policy eventually results in even higher interest rates, and a more prolonged period with output below potential. There are also important asymmetries, such that the central bank response to unfavorable supply shocks has to be more vigorous than its response to favorable supply shocks.

The variety of outcomes from differing starting points and different shocks reflects the forward-looking, flexible, approach to IT embedded in the model. The simplest types of 
conventional reaction function, in contrast, have fixed inflation targets, and adjust the policy interest rate on the basis of observed movements in target variables, regardless of the source of the shock. ${ }^{6}$ Flexibility, however, is useful only when used in line with the low inflation objective. Actions - or delays - inconsistent with the objective carry a heavy cost in the model; they can result in medium-term stagflation.

The rest of the paper is organized as follows. Section II describes the model, Section III reports the results on optimal paths for disinflation for different levels of credibility, Section IV sets out the results on optimal responses to supply and demand shocks for economies with different initial conditions, and Section $\mathrm{V}$ examines the implications of delaying interest rate increases. Section VI offer some concluding remarks.

\section{The Model}

Some of the central banks that pioneered IT in the 1990s had extensive sources of data, and reasonably sophisticated macro modeling and forecasting capabilities. ${ }^{7}$ Some economists worried that having such a capability was a prerequisite for successfully introducing IT. ${ }^{8}$ As more and more central banks have successfully adopted the approach, however, such concern has faded. A recent survey of IT central banks found that most usually embarked on the strategy without having sophisticated models (Batini, Kuttner and Laxton, 2005 and Batini and Laxton, 2007). Very few had models that could produce forecasts conditional on different assumptions about monetary policy. However, IT often stimulated the development of such models, and their use in a forecasting and policy analysis system. The experience suggests that limited analytical capacity within the central bank need not be an overriding obstacle to IT but that any central bank introducing IT should, with high priority, develop appropriate models and forecasting procedures.

Technical developments in model building have made this task considerably easier. Whereas classical econometric estimation requires large data sets and long time series, more recent approaches involve calibrating parameters on the basis of a broad range of relevant evidence or using Bayesian estimation techniques. A traditional econometric approach is unlikely to

\footnotetext{
${ }^{6}$ Many central bank models insert a model-based forecast of deviations of future inflation from target in their reaction function, and these are more flexible than the simplest forms of reaction function that use only past or current deviations of inflation from target.

${ }^{7}$ This was certainly the case for the Bank of Canada, which had a long history of macro modeling and using such models for forecasting and policy analysis. The Reserve Bank of New Zealand (RBNZ) and some other central banks did not, however, have such a framework in place, and years later some of them effectively adopted the framework that was developed at the Bank of Canada - see Black and others (1994), Coletti and others (1996) and Hunt, Rose and Scott (2000). For a discussion of the history of macro modeling in central banks see The Economist, 2006.
}

${ }^{8}$ See, for example, Masson, Savastano and Sharma (1997) and Eichengreen and others (1999). 
yield reliable parameter values, because data series, especially in developing and emerging economies, are generally short and affected by structural change. ${ }^{9}$

Moreover, in macro models for IT the linkage between instruments and policy objectives is clear. Thus, even though they may contain technically complicated dynamics, the basic way that they work is relatively easy to describe to a wide audience. This means the central bank can use them, more or less informally depending on the audience, to explain central bank actions within a transparent, consistent analytical framework. Good communications are particularly important during the phase of inflation reduction, since the more effective the central bank is in persuading people that its policy is credible, the lower are the costs of disinflation.

In the end, the achievement of low inflation itself alters behavior. The widespread movement to lower inflation over the past twenty years not only has lowered the inflation rate anticipated by the public, but also has changed the process by which expectations are formed. Whereas, previously, expectations drifted with current and past inflation rates, transforming one-off shocks to the price level into prolonged inflation spirals, they are now closely anchored to the low rate targeted by the central bank in many IT countries, with the result that price shocks have only a quickly damped effect on the inflation rate. ${ }^{10}$ Our model captures such a shift by means of an inflation expectations process that over time becomes more forward-looking as stable low inflation is established.

\section{A. Inflation Process with Endogenous Credibility}

\section{A.1 Inflation equation-An expectations-eugmented Phillips curve}

The inflation equation is as follows:

$$
\begin{gathered}
\pi_{t}=\lambda_{1} * \pi 4_{t}^{e}+\left(1-\lambda_{1}\right) * \pi 4_{t-1}+\lambda_{2} *\left(\frac{y_{t-1}}{y_{\max }-y_{t-1}} y_{\max }\right)+\lambda_{3} * \Delta z_{t}+\varepsilon_{t}^{\pi} \\
\left(\lambda_{1}=0.75, \lambda_{2}=0.25, \lambda_{3}=0.10\right)
\end{gathered}
$$

where, $\pi 4_{t}^{e}$ and $\pi 4_{t-1}$ are the forward-looking and backward-looking components of inflation, $y_{t-1}$ is the output gap in period $t-1$, and $y_{\max }$ is the maximum output gap possible. $z$ (in

\footnotetext{
${ }^{9}$ Berg, Karam, and Laxton (2006a and 2006b), discuss in depth this issue as well as the process of model calibration.

${ }^{10}$ Relevant evidence is included in Laxton and N'Diaye (2002), Levin and others (2004), Goretti and Laxton (2005) and Mishkin (2007).
} 
$\operatorname{logs}$ ) is the real exchange rate (measured so that an increase is a depreciation, approximately in percentage points) and $\Delta z_{t}$ is the change in the real exchange rate $\left(z_{t}\right)$ from last period's level $\left(z_{t-1}\right) . \lambda_{1}$ and $\lambda_{2}$ are model parameters and $\epsilon_{t}^{\pi}$ is the supply shock.

The terms in the equation represent, from left to right:

- forward-looking and backward-looking components to the expectations process-with an endogenous credibility stock in the forward-looking component

$\left(\lambda_{1} * \pi 4_{t}^{e}+\left(1-\lambda_{1}\right) * \pi 4_{t-1}\right)$

where $\pi 4_{t-1}=\frac{1}{4} \sum_{i=1}^{4} \pi_{t-i}$. We will characterize the way in which inflation expectations $\left(\pi 4_{t}^{e}\right)$ are formed in the next sub-section.

- non-linear output gap effect $\left(\lambda_{2} *\left[\frac{y_{t-1}}{y_{\max }-y_{t-1}} y_{\max }\right]\right)$.

- exchange rate pass-through $\left(\lambda_{3} * \Delta z_{t}\right)$.

Expectations process and credibility. The following equation contains a mechanism that allows the formation of expectations to change from a drifting, backward-looking, process to one which is anchored by the low-inflation target, in line with the evidence.

$$
\pi 4_{t}^{e}=\gamma_{t} * \pi 4_{t+4}+\left(1-\gamma_{t}\right) * \pi 4_{t-1}+b_{t}+\varepsilon_{t}^{\pi^{e}}
$$

The first two terms in the equation for expected inflation comprise a weighted average of a model-consistent forecast of the 4-quarter ahead year-on-year inflation rate (forward-looking component) and the year-on-year inflation rate observed last quarter (backward-looking component). The weight on the forward-looking component, $\gamma_{t}$, ranges between 0 (no credibility) and 1 (full credibility) and is a measure of the stock of credibility.

In order to define the evolution of the credibility stock, we postulate that the public sees a possibility of one of two inflation regimes - ' $\mathrm{L}$ ' and ' $\mathrm{H}$ ', for 'Low' and 'High' inflation. In the ' $\mathrm{L}$ ' scenario, inflation would converge to the announced inflation target $\left(\pi^{*}\right):^{11}$

$$
\begin{gathered}
\pi 4_{t}^{L}=\Upsilon^{L} * \pi 4_{t-1}+\left(1-\Upsilon^{L}\right) * \pi^{*}+\varepsilon_{t}^{\pi^{L}} \\
\left(\Upsilon^{L}=0.6, \pi^{*}=3\right)
\end{gathered}
$$

The ' $\mathrm{H}$ ' scenario corresponds to a suspicion in the public mind that monetary policy might deliver an inflation rate much higher than the announced target-we suppose that rate to be 40 percent. Under the $\mathrm{H}$ scenario, inflation would converge to 40 percent:

$$
\pi 4_{t}^{H}=\Upsilon^{H} * \pi 4_{t-1}+\left(1-\Upsilon^{H}\right) * 40+\varepsilon_{t}^{\pi^{H}}
$$

${ }^{11}$ The inflation target is defined as the mid-point of the target range. 


$$
\left(\Upsilon^{H}=0.9\right)
$$

We use these potential scenarios to define a credibility coefficient, $\eta_{t}$

$$
\eta_{t}=\frac{\left(\pi 4_{t}^{H}-\pi 4_{t}\right)^{2}}{\left(\pi 4_{t}^{H}-\pi 4_{t}\right)^{2}+\left(\pi 4_{t}^{L}-\pi 4_{t}\right)^{2}}
$$

The coefficient $\eta_{t}$ gauges the extent to which inflation outcomes are seen as consistent with the 'Low' inflation scenario. Consider two extreme cases. ${ }^{12}$ In the ' $L$ ' case, inflation converges gradually to the inflation target as implied by equation (3). $\eta_{t}$ equals 1 , since the term $\left(\pi 4_{t}^{L}-\pi 4_{t}\right)$ in the denominator of equation (5) equals $0^{13}$. If inflation is at the level postulated in the ' $\mathrm{H}$ ' case, on the other hand, $\eta_{t}$ equals 0 , implying a complete lack of credibility. Credibility is lost—people give increased weight to a suspected high inflation scenario-if inflation outcomes are above the announced target.

The credibility stock $\left(\gamma_{t}\right)$ then evolves in the following autoregressive form:

$$
\begin{gathered}
\gamma_{t}=\rho * \gamma_{t-1}+(1-\rho) * \eta_{t-1}+\varepsilon_{t}^{\gamma} \\
(\rho=0.18)
\end{gathered}
$$

An increase in $\eta_{t}$ results in a rise in the weight on the forward-looking component of expectations. ${ }^{14}$ This ties inflation more tightly to the target, such that the central bank has to do less in response to shocks, and convergence to the target rate is faster. The disturbance term, $\varepsilon_{t}^{\gamma}$ represents a shock to central bank credibility, which may be positive or negative.

The one-year-ahead inflation expectations implied by the hypothetical ' $L$ ' and ' $H$ ' equations, (3) and (4), are as follows:

$$
\pi 4_{t}^{e, L}=\left(1-\Upsilon^{L}\right) * \pi^{*} * \sum_{i=0}^{3}\left(\Upsilon^{L}\right)^{i}+\left(\Upsilon^{L}\right)^{4} * \pi 4_{t}
$$

\footnotetext{
${ }^{12}$ We can think of the inflation expectations specified in equations 7 and 8 as evolving according to a first-order, stationary autoregressive process, reverting in the long run to the targeted level of inflation in the ' $\mathrm{L}$ ' case and $40 \%$ in the ' $\mathrm{H}$ ' case. The parameter values on lagged inflation are indicative of the rate of convergence to the steady state, with high persistence values implying a longer time to converge.

${ }^{13}$ This term is the expectation error of the low hypothetical inflation expectation.

${ }^{14}$ The convergence rate parameter of the credibility stock was calibrated to 0.18 ; i.e., it takes more than 4 years for credibility to rebuild from some less than full level of initial credibility.
} 


$$
\begin{gathered}
\pi 4_{t}^{e, H}=\left(1-\Upsilon^{H}\right) * 40 * \sum_{i=0}^{3}\left(\Upsilon^{H}\right)^{i}+\left(\Upsilon^{H}\right)^{4} * \pi 4_{t} \\
\left(\Upsilon^{L}=0.6, \Upsilon^{H}=0.9\right)
\end{gathered}
$$

The inflation expectations 'bias', $b_{t}$, is simply defined as a proportion of the deviation of a weighted average of hypothetical inflation expectations from the inflation target, where the weights reflect the credibility stock $\gamma_{t}$ :

$$
b_{t}=0.2 *\left(\gamma_{t} * \pi 4_{t}^{e, L}+\left(1-\gamma_{t}\right) * \pi 4_{t}^{e, H}-\pi^{*}\right)
$$

Based on this equation, as credibility approaches unity, the bias converges to zero, since $\pi 4_{t}^{e, L}$ will tend to converge to the inflation target. Under the no credibility scenario $\left(\gamma_{t}=0\right)$, the inflation bias is positive and is proportional to the difference between the high hypothetical inflation expectations and the target. ${ }^{15}$

Nonlinear output gap effect Empirical evidence suggests that the effect of the output gap on inflation is nonlinear (e.g. Debelle and Laxton, 1997). In equation (1), we introduced a strongly increasing impact on inflation as output approaches its maximum value, as follows:

$\lambda_{2} *\left(\frac{y_{t-1}}{y_{\max }-y_{t-1}} y_{\max }\right)$

The parameter $\lambda_{2}$ captures the marginal effect on inflation of an increase in the output gap when the output gap is near zero. This term also implies that the output gap cannot exceed a maximum value of $y_{\max }$. We set $y_{\max }$ equal to 5 percent in the model simulations. Thus, as the gap approaches 5 percent, it has an ever-increasing effect on the inflation rate. This puts a limit on the extent to which expansion of demand can stimulate an increase in output: at $y_{\max }$, increases in demand result only in increasing inflation. Because of this non-linearity, an economy operating with an output gap near the maximum will subsequently have to incur long periods of negative output gaps to restore the desired inflation rate.

\section{A.2 Output Gap equation}

Domestic output depends on the real interest rate, the real exchange rate, and demand in the rest of the world, represented by the United States. ${ }^{16}$

\footnotetext{
${ }^{15}$ Clear evidence of inflation bias stemming from a credibility problem is seen in the behaviour of the inflation premium in the UK bond market before 1997 (Freedman, Laxton and Ötker-Robe, 2008).

${ }^{16}$ Representations such as this one are usually motivated with a first-order condition consistent with optimizing consumers with habit formation. See Smets and Wouters (2003) or Laxton and Pesenti (2003) for a linearized
} 
The equation is written in terms of deviations from equilibrium values. The output gap is the deviation, in percentage points, of actual output from a measure of the trend or equilibrium level of GDP (a positive number indicates that output is above trend). It is a function of the gap between the actual real interest rate and its equilibrium value, the real exchange rate gap, and the US output gap. Dynamics are added through the influence of past and future domestic output gaps, and lagged reactions to the interest rate and exchange rate gaps:

$$
\begin{gathered}
y_{t}=\beta_{l} * y_{t-1}+\beta_{2} * y_{t+1}-\beta_{3} *\left(r r_{t-1}-\overline{r r}_{t-1}\right)+\beta_{4} *\left(z_{t-1}-\bar{z}_{t-1}\right)+\beta_{5} * y_{t}^{U S}+\varepsilon_{t}^{y} \\
\left(\beta_{1}=0.75, \beta_{2}=0.10, \beta_{3}=0.20, \beta_{4}=0.10, \beta_{5}=0.20\right)
\end{gathered}
$$

where $r r$ is the real interest rate in percentage points, $y_{t}^{U S}$ is the U.S. output gap, and the bar above a variable denotes the equilibrium value of the variable. The term $\varepsilon_{t}^{y}$ represents a demand shock.

\section{A.3 Exchange rate-real interest rate parity equation}

There are two differences between the real uncovered interest parity (IP) equation in this model and classic uncovered interest parity. First, there is a country risk premium. Second, the expected exchange rate is a weighted average of a forward-looking, model-consistent component, and a backward-looking component. The current value of the real exchange rate is thus a function of the expected value of the real exchange rate, the differential between domestic and foreign real interest rate gaps, the risk premium, and a disturbance term. Portfolio preference shocks, e.g., exchange market disturbances, which can be large for emerging-market economies, are contained in the disturbance term $\varepsilon_{t}^{z}$. The equation for the current exchange rate equation may thus be written (in logs) as:

$$
\left[r r_{t}-r r_{t}^{U S}\right] / 4=\left(z_{t+1}^{e}-z_{t}\right)+\left[\overline{r r}_{t}-\overline{r r}_{t}^{U S}\right] / 4+\varepsilon_{t}^{z}
$$

where $r r_{t}^{U S}$ is the U.S. real interest rate and $\overline{r r}_{t}-\overline{r r}_{t}^{U S}$ is the equilibrium risk premium. And the expected real exchange rate equation is as follows:

$$
\begin{gathered}
z_{t}^{e}=\varphi * z_{t+1}+(1-\varphi) * z_{t-1} \\
(\varphi=0.90)
\end{gathered}
$$

version of the Euler equation for consumption that depends on lagged and expected consumption, real interest rates and a habit-persistence parameter. However, habit persistence alone cannot account for a very large weight on the lagged output gap, which is resolved in DSGE models by adding investment to the model and significant adjustment costs associated with changing the levels of investment. 


\section{A.4 Monetary policy loss function}

Under IT, by definition, the loss function will attach a high cost to deviations of inflation from target. In the short run, monetary actions also affect interest rates and output, and policymakers are averse to deviations of output from potential and to significant variability of the interest rate from one period to the next. Aiming to keep output near its potential level-i.e. minimizing the amplitude of the business cycle - has an obvious justification since this is a fundamental objective of macroeconomic policy.

Aversion by central banks to sharp movements in the policy interest rate, which is evident in their widely observed practice of adjusting interest rates only gradually in response to changes in economic conditions, has a more technical rationale. Whereas the policy interest rate controlled by the central bank is a very short-term rate, the market interest rates that affect spending and output are medium-term and longer-term. Effective transmission of policy actions is facilitated by market rates responding predictably to movements in the policy rate. If policy rates move gradually in response to changes in economic conditions, financial markets will project that a change this quarter will have some duration in the quarters ahead. Medium-term and longer-term rates, which incorporate expectations of the future policy rate, then respond relatively strongly to policy actions. ${ }^{17}$ High quarter-to-quarter variability in the policy rate, on the other hand, would reduce its impact on relevant market rates, and thereby weaken the effectiveness of policy transmission.

With these considerations in mind, the loss function in the model cumulates a weighted sum of:

- squared deviations from the inflation target

- squared output gaps, and

- squared one-quarter changes in the policy interest rate

$$
\operatorname{Los}_{t}=\sum_{t=1}^{\infty}\left[\omega_{1}\left(\pi 4_{t}-\pi^{*}\right)^{2}+\omega_{2} y_{t}^{2}+\omega_{3}\left(r s_{t}-r s_{t-1}\right)^{2}\right]
$$

$\left(\right.$ Case 1: $\left.\omega_{1}=1, \omega_{2}=1, \omega_{3}=1\right)$

$\left(\right.$ Case $\left.2: \omega_{1}=1, \omega_{2}=0.25, \omega_{3}=0.25\right)$

The weights $\left(\omega_{i}\right)$ embody the costs that policymakers attach to each of these items. Monetary policy minimizes this loss function, subject to the constraints imposed by the structure of the model. Monetary policy has choices with respect to the path towards the inflation target. This

\footnotetext{
${ }^{17}$ Along these lines, Woodford (2003) argues that a strategy of gradual interest adjustment may be optimal.
} 
may be fast, if the cost of inflation misses is high relative to the costs of output gaps and interest rate instability. Or it may be slow, if the cost of inflation-targeting errors is relatively low.

The quadratic loss function implies symmetric aversion to overshoots and undershoots with respect to the inflation target. One might argue that policymakers' preferences would not be symmetric under a program of inflation reduction. They might regard an undershoot of inflation as a benign, albeit unexpectedly rapid, approach to the low-inflation objective, but an overshoot as a serious threat to the program. Despite the symmetric loss function, the full model does not imply symmetric policy responses since endogenous credibility results in a stronger interest rate response to overshoots than to undershoots.

\section{A.5 Note on calibration}

Calibration parameter values are reported under their respective equations. These parameters were selected so that the model generated dynamics that capture the data consistent with stylized facts. The most critical parameter variables are those of the Phillips curve $\left(\lambda^{\prime} s\right)$. The parameters have been chosen such that a typical Phillips curve is generated. In this Phillips curve, there is considerable weight on both forward and backward looking components, consistent with the data and agents' behavior.

\section{Optimal Disinflation}

\section{A. Initial Conditions}

In small macro models with exogenous credibility, the optimal speed of disinflation is a function of two main factors. One is the flexibility of the economy, in the form of the response of aggregate demand to real interest rates and the real exchange rate and the response of inflation to the output gap. The second is the extent which inflation expectations are forward-looking or backward-looking. An additional element in the optimal disinflation path that is missing in such models but plays a crucial role in our model is endogenous credibility. This involves the way in which the achieved rate of inflation along the disinflation path will lead to an increase in credibility over time and consequently cause expectations to become more forward-looking. These linkages between inflation, credibility, and the process of expectations formation have important implications for the relationship between the initial stock of credibility and the optimal path for disinflation, as will be illustrated in this section of the paper. They also have important implications for the appropriate reaction of the authorities

to supply and demand shocks, as will be discussed in the next section of the paper. The way in which we illustrate the importance of credibility for disinflation is to show the sensitivity of the speed and duration of the optimal disinflation path to the initial stock of credibility. 
The economy under study is assumed to begin with an $8 \%$ rate of inflation and to have a long-term inflation target of 3\%. Its equilibrium real interest rate is $2.5 \%$, its initial nominal interest rate is $10.5 \%$ (consistent with the existing rate of inflation and the equilibrium real interest rate) and the output gap is initially zero. We assume that the central bank announces the long-run target for the inflation rate of $3 \%$ in period 0 and adjusts its policy interest rate starting in period 1 to implement the loss-minimizing strategy to achieve its objective.

\section{B. Disinflation Under Various Degrees of Credibility}

In the model, credibility can vary between zero (no credibility) and one (perfect credibility). Values of credibility below one are imperfect in the sense that people do not have 100 percent confidence that the central bank will achieve its announced objective, and may not even believe that the bank will try to achieve it. In forming their expectations of inflation, people give considerable weight to the recent history of inflation, and to the risk that policymakers might have a covert high-inflation agenda. In figure 1 we present the results of three alternative starting points for credibility - an initial stock of credibility equal to one (the solid line), initial credibility of 0.5 in which monetary policy has some credibility in the process of expectations formation (the line with + signs), and an initial stock of credibility of zero in which monetary policy has no credibility in the process of expectations formation (the line with circles). For comparison, we also show a situation in which the stock of credibility is held at zero exogenously for a period of eight quarters (the line with triangles). In these experiments, the central bank can earn an increased stock of credibility, but only by delivering movements in inflation consistent with the official objective.

Begin with the initial stock of credibility of zero. Nominal interest rates have to rise by about two percentage points and remain above their initial level for over a year. Given the level of inflation expectations at the outset, and the lags in the expectations process, the central bank has to raise the policy rate by this amount to engineer the required increase in the real interest rate in order to open the negative gap in output. The higher nominal interest rate has an immediate impact on the external value of the domestic currency, which appreciates in nominal and real terms against the US dollar. The increased interest rate and the real appreciation of the domestic currency together reduce the demand for domestic output. The resulting excess capacity represents the short-run output sacrifice required for disinflation in the model. The output gap declines to below minus $2 \%$ and excess supply persists for six years. The inflation rate remains virtually unchanged for over a year, and it takes more than four years for the economy to reach the target of 3\% inflation. In spite of the slow pace of disinflation initially, the stock of credibility gradually increases, since the inflation outcome is well below that of the high inflation scenario that is the source of skepticism about the commitment of the authorities to bring about a lower rate of inflation. After the initial period of sticky inflation, the rate of inflation declines gradually and the stock of credibility continues to rise. The sacrifice ratio (the cumulative foregone annual output for each percentage point of inflation decline) is about 1.35, meaning that foregone output is about 6 $3 / 4$ percent of GDP for the five percentage point decline in inflation. By historical standards, 
despite the initial low credibility, this would represent a fairly rapid, low-cost disinflation. ${ }^{18}$

At the other extreme, there is full credibility initially, with the public having full confidence from the outset in the inflation-targeting framework announced by the central bank. Thus, the expectations process is based on the view that the central bank is in fact committed to the low-inflation objective and does not have non-disclosed, high-inflation intentions. In this case, the rate of inflation declines to the 3 percent target range about two years after the central bank commits to this target. This outcome is the result of the strong, direct, announcement effect when the stock of credibility is 100 percent. The reduction in expected inflation itself raises the real interest rate above the natural rate, without any increase in the nominal rate. Indeed, the nominal rate declines throughout the disinflation phase, as the premium for expected inflation declines. With excess supply in the economy never falling below 1 percent, and output returning to potential fairly quickly, the sacrifice ratio over the two-year inflation-reduction period is just under 0.25 and foregone output is only $11 / 4$ percent of GDP.

The assumption of 100 percent credibility implies that this simulation yields the fastest path of disinflation consistent with loss minimization. In other words, the simulated path in this experiment describes the upper limit to the desirable pace of disinflation reduction.

An initial stock of credibility of 0.5 gives results that are about half way between those for zero credibility and those for full credibility. With an intermediate starting point for credibility, it takes about three years to reach the target of 3\% inflation, and the sacrifice ratio is about 0.75 , just over half that with zero credibility. Also, although nominal interest rates do not have to increase following the target announcement, they decline very little over much of the first year. After about five years, the economy is almost at its long-run equilibrium path. By that time, the stock of credibility is close to unity, and the output gap is virtually zero. The real exchange rate stabilizes at its initial equilibrium value, but the nominal exchange rate continues to depreciate slowly, reflecting the small remaining differential between domestic and US inflation.

Comparing the case in which credibility is exogenously held at zero for eight quarters and that in which it begins at zero but is allowed to adjust endogenously from the very beginning of the disinflation process, we see that the former takes about two years longer to achieve the 3\% inflation objective than the latter. It also requires higher interest rates and a more negative output gap to bring about the decline in inflation. While the simulation in which the stock of credibility is endogenous but initially zero implies a sacrifice ratio of about 1.35 , the simulation of the model of the economy with initial exogenous credibility of zero has a sacrifice ratio of about 2 .

Low credibility results in upward-biased inflation expectations. During the inflation-reduction phase people expect a rate higher than monetary policy actually delivers. Since expectations

\footnotetext{
${ }^{18}$ For example, the decline is more rapid than the announced inflation reduction targets in Table 9, Roger and Stone (2005). In some countries, however, actual inflation fell much more quickly than envisaged in the target path - see Coats, Laxton and Rose (2003) for a discussion of the experiences with Inflation Targeting in the Czech Republic.
} 
have a direct effect on actual inflation in the Phillips curve, monetary policy has to be tighter than if the public had complete confidence in the ability of the central bank to achieve its objectives, and the loss of output and employment is greater. Thus, low credibility worsens the short-run inflation-output trade-off. As excess productive capacity reduces the rate of inflation, the public gradually revises downward its expectations of future inflation and becomes more forward-looking, giving increased weight to the announced $3 \%$ target.

The difference between the easy, quick disinflation with full credibility, and the more costly, more gradual disinflation with imperfect credibility illustrates the argument put forcefully by Woodford (2005): "For not only do expectations about monetary policy matter, but at least under current conditions, very little else matters."

In figure 2, we present the disinflation scenarios for an alternative situation in which the authorities place much less weight on deviations of output from potential and on interest rate changes than in the above simulations. More precisely, rather than equal weights on all three arguments in the loss function, it is assumed that the weights on output deviations and interest rate changes are one quarter those on the deviations of inflation from target. A comparison of the results in figure 2 with those in figure 1 shown earlier indicates that, for all levels of initial credibility, the changes in the parameters of the loss function result in higher interest rates, greater excess supply, and a higher sacrifice ratio. But there is a somewhat faster movement of inflation to its long-run equilibrium.

\section{Optimal Responses to Shocks}

\section{A. Initial Conditions}

In this section of the paper, we subject two types of economy to various shocks - favorable and unfavorable supply shocks, and positive and negative demand shocks. The first type of economy is assumed to have been conducting monetary policy under a framework of inflation targeting for some period of time and to have already achieved its long-run $2 \%$ inflation target. At the time of the various shocks, it has relatively high credibility of 0.75 , its nominal interest rate is at $4.0 \%$ (and its real interest rate is therefore at the equilibrium level of $2.0 \%$ ), and it has a positive output gap of $1 \%$. In contrast, at the time of the shocks, the second type of economy has an inflation rate of $8 \%$ and has just announced its commitment to the inflation-targeting framework and to a long-run target inflation rate of $3 \%$. It has relatively low initial credibility of 0.25 , nominal interest rates are $7 \%$, implying real interest rates of $-1 \%$ (well below the equilibrium real interest rate of $2.5 \%$ ), and a positive output gap of $1 \%$ (the same as in the first type of economy). The supply and demand shocks take place in period 1.

The two types of economy that are subject to shocks in this section of the paper are intended to represent the two types of economy that have had to face the commodity price shocks under very different circumstances. The model economy with relatively high credibility represents 
mainly the advanced, industrialized economies with low inflation, but the category also includes some emerging-market economies that adopted inflation targeting some time ago and have attained a high level of credibility because of their achievement of the long-run inflation target. These economies were hit with commodity price shocks at a time when their inflation rates were low and their real interest rates were close to neutral. The model economy with relatively low credibility represents the many emerging-market economies that are more vulnerable to the commodity price shocks because at the time of the shocks their rate of inflation was overly high, their real interest rates were well below neutral, and their economy was in excess demand. Although some of them had earlier adopted inflation targeting, they did not have a very long track record delivering low inflation and hence credibility remained low. See Helbling and others (2008) for a detailed discussion of the two types of countries.

\section{B. Supply Shocks}

The first experiments under this heading are one-off, 3 percent positive and negative shocks to the disturbance term in the inflation equation-e.g., an increase in the level of world food prices that is not expected to reverse. The results for the unfavorable (positive) shock for the more credible economy are shown as dots, and the results for the favorable (negative) shock as triangles in the left-hand panels of figure 3. The results for the less credible economy with more problematic initial conditions are shown in the right-hand panels of figure 3 .

Begin with the unfavorable supply shock in the more credible economy, which starts at equilibrium for inflation and the real interest rate (although it has a small positive output gap). With 0.75 credibility, the central bank of this economy has to raise the nominal interest rate at the peak only about 2 percentage points relative to its baseline starting point, and to hold it less than 100 basis points above baseline after about a year. There is an appreciation of the domestic currency of just over 1\% that lasts for about a year before gradually dissipating. The modest tightening of monetary conditions is sufficient to cause the upward pressure on inflation to start reversing after about a year and to return to baseline (and equilibrium) after about two years, followed by a small undershoot. In the course of bringing about the return to baseline, policy causes the output gap to move into excess supply, but by less than one percentage point. The ability of policy to offset the unfavorable supply shock with relatively little difficulty is the result of the public's inflation expectations being anchored reasonably strongly to the target.

Turning to the favorable supply shock in the more credible economy, we find that interest rates hardly adjust. The reason is that the favorable supply shock puts downward pressure on inflation at a time when the positive initial output gap would otherwise have required an interest rate increase to prevent it from pushing inflation above target.

In the case of an unfavorable supply shock in the less credible economy with more problematic initial conditions, the movements in interest rates, inflation and the output gap are both larger and more prolonged than in the case of the more credible economy. In this 
situation, the nominal interest rate has to rise from $7 \%$ to almost $15 \%$ subsequent to the shock. To some extent, the increase in interest rates was needed because of the starting point problem of real interest rates being negative and the output gap being positive. The lack of credibility also plays an important role in that the upward pressure on inflation prevents the credibility stock from increasing as fast as it otherwise would have in the context of the disinflation. Thus, it takes longer for expectations to become more forward-looking and thereby to become more anchored because of the rise in inflation over the first year to almost $10 \%$. The output gap falls to $-3 \%$ during the second year and remains below baseline for over six years.

A favorable supply shock clearly has positive benefits for the less credible disinflating economy, allowing it to achieve its new equilibrium with considerably smaller output gaps, lower nominal interest rates, and lower transitional inflation than baseline. Nonetheless, interest rates still have to rise because of problems associated with low real interest rates and excess demand at the time of the shock.

There are a number of lessons that can be drawn from this analysis. The results are in line with the experience of the past two decades in many countries that have moved from high inflation to stable low inflation. In the 1970s and 1980s, unstable inflation expectations in many countries transformed price level shocks-e.g., energy price increases and currency depreciations - into prolonged inflation spirals. Monetary policy contained the problem in the end, but only with very aggressive policy actions and at the cost of a substantial output loss. Since the early 1990s, however, many central banks have re-established a low-inflation environment and monetary policy credibility. In many inflation-targeting countries, the public now has confidence that the low-inflation policy objective will prevail, even after substantial shocks to the price level. This has substantially lessened, and in some cases has virtually eliminated, the second round of price increases.

The difficulty faced by policymakers with respect to an unfavorable supply shock in the less credible economy is that policy has to guard against an inflationary spiral, as the short-run increase in inflation causes the public to expect higher inflation in the future and to lose confidence to some extent in the announced longer-term inflation objective. As a consequence, policy needs to generate considerably higher interest rates, which in turn lead to the opening of an appreciable negative output gap. Thus, policymakers are faced with upward pressure on inflation and downward pressure on output at the same time, resulting in a form of stagflation. As shown in the figures, the loss-minimizing policy calls for a substantial and prolonged increase in the interest rate relative to the base case. In part, the increase is needed to return the real rate of interest to a neutral level; in part, it is needed to contain the pressures on inflation arising from the price shock and, to a much lesser extent, from the initial excess demand. This reaction, and the large appreciation of the exchange rate that accompanies it for a couple of years, does not prevent a prolonged divergence of inflation from the optimal path for disinflation without the shock. The main reasons for this are the adverse, self-reinforcing, impact of the increase in inflation on expectations and credibility, and the lags in response of the output gap to interest rate and exchange rate movements along with the lags of inflation in response to movements in the output gap. 
Favorable and unfavorable supply shocks have somewhat more symmetric implications under conditions of high monetary policy credibility than under conditions of low credibility. The asymmetries during the process of inflation reduction and credibility building are no longer present. These contrasts between low and high credibility situations again illustrate Michael Woodford's dictum about the paramount importance of expectations. Thus, in comparing the results with low and high credibility, one can attribute the major part of the policy problem with an unfavorable supply shock to the weak anchor for inflation expectations.

It is clear that an exogenous price level increase presents a very difficult problem for monetary policy in the absence of well-anchored expectations. An exogenous price level decrease, in contrast, allows for the possibility of inflation declining more rapidly than in the baseline. This appears to suggest the benefits of a policy of "opportunistic disinflation" (Meyer, 1996 and Orphanides and Wilcox, 2002) in which the central bank would wait for favorable supply shocks to occur and then take advantage of them to bring about a less costly disinflation. The strategy also called for a strong reaction to "incipient increases in inflation" or "sustaining the expansion and preventing an acceleration in inflation". However, the opportunistic disinflation model did not take account of endogenous shifts in credibility associated with letting inflation getting stuck at moderate levels. Waiting for favorable supply shocks in the context of the disinflation strategy under imperfect credibility would suffer from a potential loss of credibility in a stochastic setting.

The potential size and duration of the effects of unfavorable supply shocks on the inflation rate, even when policy provides appropriate resistance, is a major reason for avoiding rigid adherence to pre-announced short-run target ranges during a process of disinflation. It would be better for the central bank to set out the baseline disinflation path as a conditional forecast in the absence of shocks, and explain to the public the impact of shocks on the optimal path to the long-run equilibrium. In particular, it would have to explain that an unfavorable supply shock would lead to higher inflation and lower output on the way to the long-run target and a longer time period to arrive at equilibrium.

\section{Demand Shocks}

The two simulated demand shocks — one expansionary, the other contractionary - represent one-off exogenous changes in domestic demand of 1.0 percent of GDP in period 1. That is, these are positive and negative shocks to the disturbance term in the output gap equation of one period duration. The results for the high credibility economy are shown in the left-hand side panels of figure 4 and those for the low credibility economy are shown in the right-hand panels of figure 4.

For the expansionary shock (dots), the model indicates that the appropriate policy action in both types of economy would be to raise the interest rate at once, and quite sharply relative to the baseline simulation. Thus, the interest rate in periods 2 and 3 would be between 2 and 3 percentage points above baseline. In levels, this would mean a peak policy rate in period 2 of 
about $71 / 2 \%$ for the more credible economy and about $15 \%$ for the less credible economy. Once again, the high level in the latter case is partly in response to the low levels of real interest rates at the time the shock. In response to this increased tightening, the real exchange rate appreciates as much as 3\% relative to baseline and then starts depreciating back to its original level. The robust policy action, which accepts a sharp change in the exchange rate, achieves its purpose: the positive output gap is eliminated within a year; inflation is held close to its baseline path along on the way to the long run target; and the stock of policy credibility is maintained very close to baseline. While the output gap reaches a low of about $21 / 2 \%$ excess supply in the less credible economy, this can be attributed in large part to the unfavorable initial starting conditions.

More generally, for positive demand shocks in this model:

- the appropriate policy reaction involves a prompt, sharp change in the interest rate, and hence in the exchange rate;

- the strong interest rate action effectively mitigates the impact on the goal variables, output and inflation.

The contractionary shocks (triangle) require less policy action and less movement from baseline because they act in the direction of eliminating the initial output gap, which would have been necessary in any case.

If the expansionary demand shock were such as to bring the output gap near its maximum of

$5 \%$, there would be considerably greater asymmetry between the results of that shock and the contractionary shock. However, in the absence of such a large shock, the two shocks lead to fairly symmetrical results.

To sum up, in model simulations, policy deals relatively easily with the normal range of demand shocks, even when credibility is low. This is a common feature in macro models. Since the monetary instrument operates directly through demand, policy can promptly eradicate the problem once it is recognized. Blanchard and Galí (2007) described this as a "divine coincidence" because interest rates affect both output and inflation in the same direction and thereby facilitate the central bank response to demand shocks.

\section{Costs of Delaying Interest Rate Increase Under Imperfect Credibility}

Suppose that the less credible economy is hit by an unfavorable supply shock in period 1 but the central bank puts off the required interest rate increases until period 3, out of concern for maintaining the level of output. According to the model, a delayed interest rate response (dot) 
shows serious inflationary consequences relative to the optimal responses (triangle), as can be seen in figure 5. For several years there is a considerable deviation between the inflation rate under the interest rate delay scenario and the optimal scenario. Following the initial two quarter hesitation, the interest rate has to play catch-up, and eventually has to rise to higher levels than in the optimal scenario and to remain higher for more than five years. A short-run, low interest rate policy in the face of inflation shocks turns into a long-run, high interest rate policy. An erosion of credibility is, not surprisingly, a large part of the problem. The stock of credibility remains below baseline as the inflation rate rises above baseline.

The delay in raising the interest rate does support demand in the short run, but only at the cost of much higher inflation and higher nominal interest rates for a considerable length of time. But the combination of initial conditions, the objective of disinflation and the need to respond to the unfavorable supply shock requires that a negative output gap be opened, and after two years, the gap is wider than in the baseline for the low credibility environment. Thus, the cost of the monetary policy delay is several years of stagflation. It is also the case that delaying the interest rate response to a supply shock leaves the economy more exposed to subsequent unfavorable supply shocks.

\section{Concluding Remarks}

The low credibility version of our IT model incorporates key elements of the difficulties that the authorities undertaking a disinflationary monetary policy have to confront in many emerging-market economies. These include expectations that recent inflation rates will likely continue in the future, and the low credibility of the announcement of a new regime of low inflation. We also incorporate a policy loss function that recognizes the preference of the authorities to contain deviations of output from its potential level and to limit the variability in the interest rate, in addition to limiting deviations of inflation from its target.

The model is calibrated on the basis of a wide range of international experience. It allows the central bank to build credibility over time through consistent pursuit of a low-inflation goal. The ultimate target for low inflation acts as the nominal anchor for the economy. From this foundation, and for given initial conditions, one can derive a forecast of the optimal inflation outcomes along the disinflation path in the absence of major shocks. It is clear from the simulations that a loss-minimizing monetary policy should not be locked into a rigid predetermined path of inflation reduction. In the long run, if monetary policy consistently holds inflation to the target rate, even a skeptical public will come to firmly expect that low rate of inflation to continue.

Model simulations bear out some rather intuitive lessons. Inflation targeting provides a feasible solution to an inflation problem, despite unpromising initial conditions. Policy can achieve the low-inflation goal more rapidly, and with less short-run loss of output, the greater is its credibility. Monetary policy can deal with cyclical demand shocks relatively easily, because the monetary instrument itself acts through demand channels. Supply shocks are 
more awkward, with greater asymmetries in the appropriate policy responses to unfavorable and favorable shocks. Thus, policy has to respond more vigorously to inflationary than to disinflationary impulses. Favorable supply shocks actually help a disinflationary policy achieve its objectives, with smaller interest rate increases on the disinflation path than otherwise necessary. But adverse supply shocks - exogenous increases in prices - present the most difficult problems for inflation control, particularly if inflation expectations are not well anchored. During the process of disinflation, the effects of supply shocks on inflation can be large and of significant duration, even with an appropriate policy response. This is an important reason for avoiding rigid adherence to short-term inflation-reduction targets. During the early part of the disinflation path, the central bank has to be prepared to raise interest rates to a level that dampens demand and brings about visible reductions in inflation. Any hesitation, out of excessive concern for limiting short-run output losses, damages credibility, delays the achievement of the low-inflation goal, and results in more prolonged output losses: in a word, stagflation. 


\section{References}

Argov, E. N. Epstein, P. Karam, D. Laxton, and D. Rose, 2007, "Endogenous Monetary Policy Credibility in a Small Macro Model of Israel,” IMF Working Paper 07/207 (Washington: International Monetary Fund).

Batini, N., K. Kuttner, and D. Laxton, 2005, “Does Inflation Targeting Work in Emerging Markets?" Chapter 4 (September 2005) World Economic Outlook, International Monetary Fund, available at www.imf.org.

Batini, N. and D. Laxton, 2007, "Under What Conditions Can Inflation Targeting Be Adopted? The Experience of Emerging Markets,' in Monetary Policy Under Inflation Targeting," ed. by F. S. Mishkin and K. Schmidt-Hebbel (Chile: Banco Central de Chile), pp. 467-506.

Berg, A., P. Karam, and D. Laxton, 2006a, “A Practical Model-Based Approach to Monetary Policy Analysis - Overview,” IMF Working Paper 06/080 (Washington: International Monetary Fund).

__ 2006b, "Practical Model-Based Monetary Policy Analysis-A How-to Guide," IMF Working Paper 06/081 (Washington: International Monetary Fund).

Black, R., D. Laxton, D. Rose, and R. Tetlow, 1994, “The Steady-State Model: SSQPM,” The Bank of Canada's New Quarterly Projection System, Part 1, Bank of Canada, Technical Report No. 72.

Blanchard, O., and J. Galí, 2007, "Real Wage Rigidities and the New Keynesian Model," Journal of Money, Credit and Banking, Supplement to Vol. 39, No. 1, pp 35-65.

Coats, W., D. Laxton and D. Rose, 2003, “The Czech National Bank's Forecasting and Policy Analysis System,” (Prague, Czech Republic: Czech National Bank).

Coletti, D., Hunt, B., D. Rose, and R. Tetlow, 1996, “The Dynamic Model: QPM,” The Bank of Canada's New Quarterly Projection System, Part 3, Bank of Canada, Technical Report No. 75.

Debelle, G., and D. Laxton, 1997, "Is the Phillips Curve Really A Curve? Some Evidence for Canada, The United Kingdom and the United States," Staff Papers, International Monetary Fund, Vol. 44, No. 2, June, pp. 249-82.

Eichengreen, B., P. Masson, M. Savastano and S. Sharma, 1999, "Transition Strategies and Nominal Anchors on the Road to Greater Exchange-Rate Flexibility," Essays in International Finance, Vol. 213, Princeton.

Freedman, C., D. Laxton, and I. Ötker-Robe, 2009, "Inflation Targeting: Saying What You Do and Doing What You Say," forthcoming. 
Goretti, M. and D. Laxton, 2005, "Long-Term Inflation Expectations and Credibility," Box 4.2 in Chapter 4 (September 2005), World Economic Outlook, International Monetary Fund, available at www.imf.org.

Helbling, T., D. Laxton, V. Mercer-Blackman, and I. Tytell, 2008, “Is Inflation Back? Commodity Prices and Inflation,” Chapter 3 (October 2008), World Economic Outlook, International Monetary Fund, available at www.imf.org.

Hunt, B., D. Rose, and A. Scott, 2000, "The Core Model of the Reserve Bank of New Zealand's Forecasting and Policy System,” Economic Modelling 17, (April), pp. 247-74.

Isard, P., D. Laxton, and A. Eliasson, 2001, "Inflation Targeting with NAIRU Uncertainty and Endogenous Policy Credibility," Journal of Economic Dynamics \& Control, Vol. 25, pp. $115-48$.

Laxton, D., and P. N’Diaye, 2002, "Monetary Policy Credibility and the Unemployment-Inflation Trade-Off: Some Evidence from 17 Industrial Countries," IMF Working Paper 02/220 (Washington: International Monetary Fund).

Laxton, D., and P. Pesenti, 2003,"Monetary Policy Rules for Small, Open, Emerging Economies," Journal of Monetary Economics, Vol. 50 (July), pp. 1109-46.

Levin, A., F. Natalucci and J. Piger, 2004, “The Macroeconomic Effects of Inflation Targeting," The Federal Reserve Bank of St. Louis Review, July/August, pp. 51-80.

Masson, P., M. Savastano, and S. Sharma, 1997, “The Scope for Inflation Targeting in Developing Countries,” IMF Working Paper 97/130 (Washington: International Monetary Fund).

Meyer, L., 1996, “Monetary Policy Objectives and Strategy,” Remarks Delivered at the National Association of Business Economists 38th Annual Meeting, Boston, Massachusetts September 8, 1996, http://www.federalreserve.gov/boarddocs/speeches/1996/19960908.htm

Mishkin F., 2007, “Inflation Dynamics,” Annual Macro Conference, Federal Reserve Bank of San Francisco, (March), http://www.federalreserve.gov/news events/speech/mishkin20070323a.htm

Mishkin, F., and K. Schmidt-Hebbel, 2001, "One Decade of Inflation Targeting in the World: What Do We Know and What Do We Need to Know?" in Norman Loayza and Raimundo Soto, eds., Inflation Targeting: Design, Performance, Challenges (Central Bank of Chile: Santiago, 2001): pp. 117-219.

Orphanides, A., and D. W. Wilcox, 2002, "The Opportunistic Approach to Disinflation," International Finance, Vol. 5, pp. 47-71.

Roger, S., and M. Stone, 2005, "On Target? The International Experience with Achieving Inflation Targets," IMF Working Paper 05/163 (Washington: International Monetary Fund). 
Smets, F., and R. Wouters, 2003, “An Estimated Stochastic Dynamic General Equilibrium Model of the Euro Area," Journal of European Economics, Vol. 49, pp. 947-81.

Svensson, L., 1997, "Inflation Forecast Targeting: Implementing and Monitoring Inflation Targets," European Economic Review 41, pp. 1111-1146.

The Economist, 2006, "Big Questions and Big Numbers-Economic Models," Special Report, (July), pp. 67-69.

Woodford, M., 2003. “Optimal Monetary Policy Inertia,” Review of Economic Studies, (2005), Vol. 70, pp. 861-86.

, 2005, “Central-Bank Communication and Policy Effectiveness,” Federal Reserve Bank of Kansas City, Jackson Hole Symposium The Greenspan Era: Lessons for the Future (August). 
Figure 1: Disinflation with Equal Weights on Inflation, Output and Interest Rate Variability

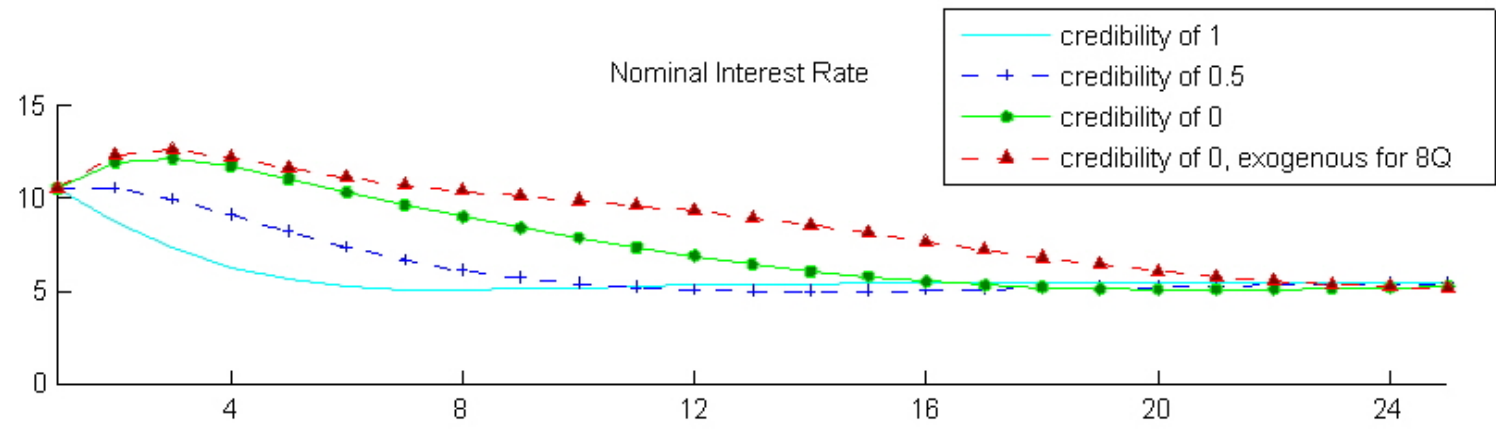

YoY Inflation

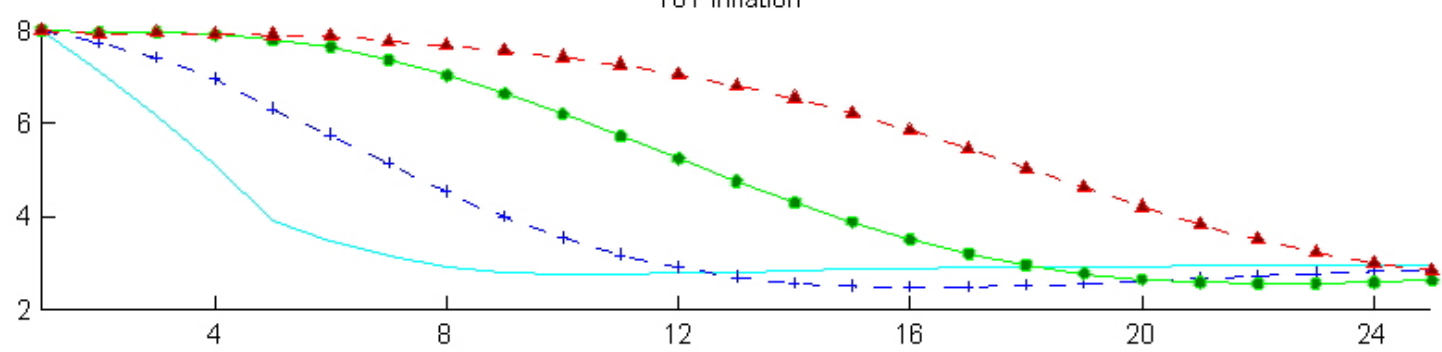

Credibility Stock

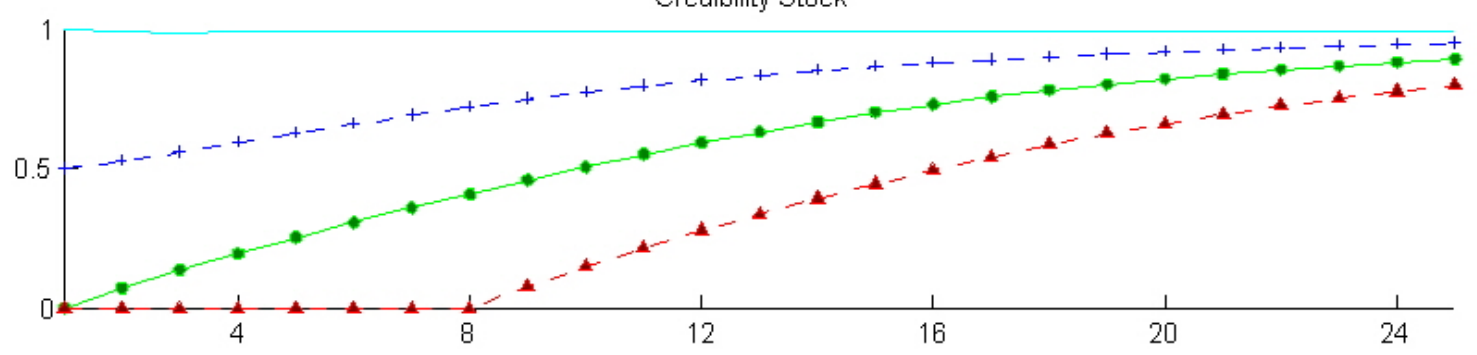

Output Gap

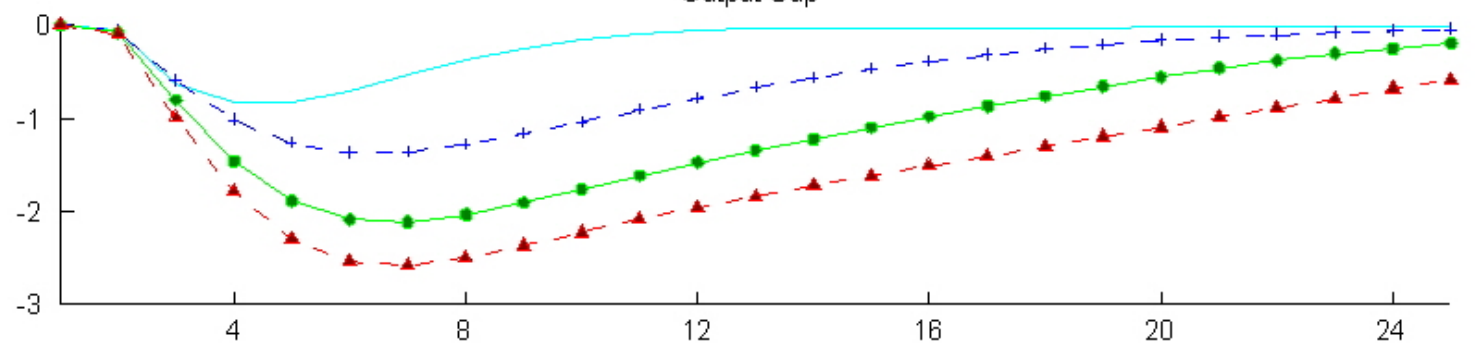

Sacrifice Ratio

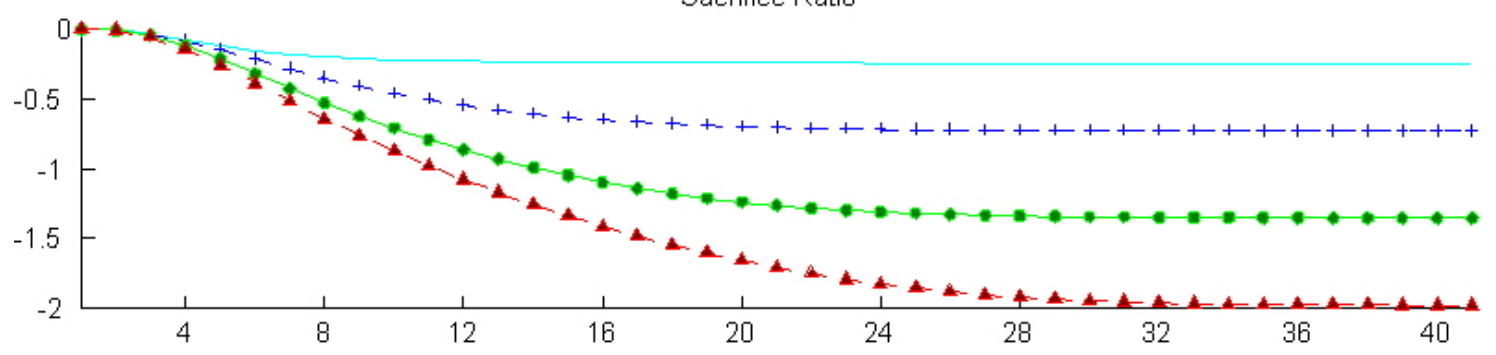


Figure 2: Disinflation with Lower Weights on Output and Interest Rate Variability

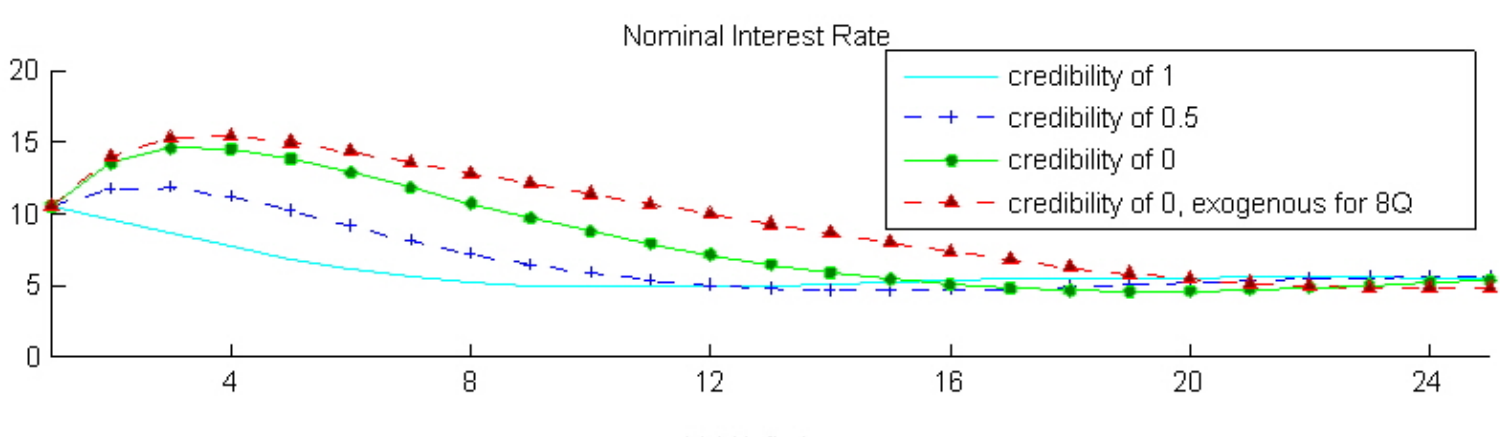

YoY Inflation

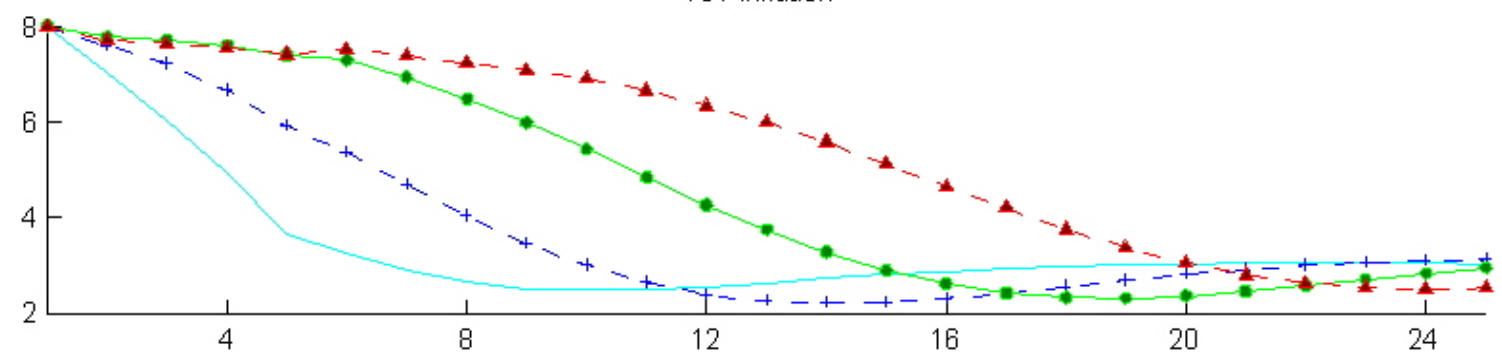

Credibility Stock

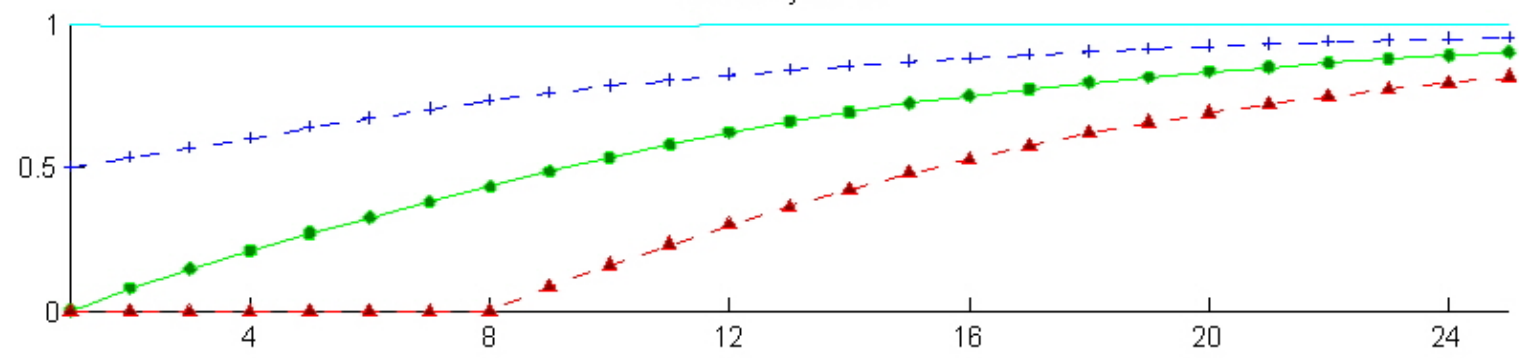

Output Gap

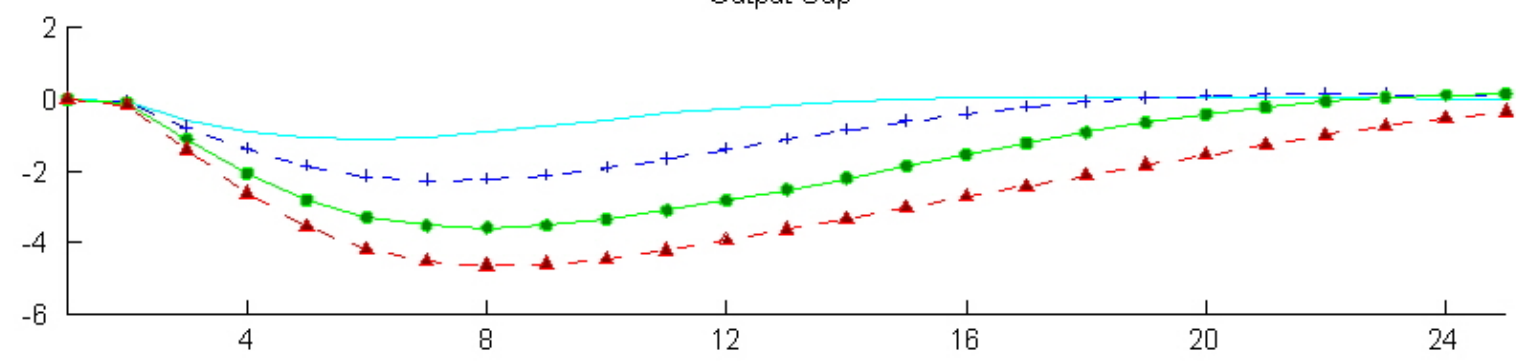

Sacrifice Ratio

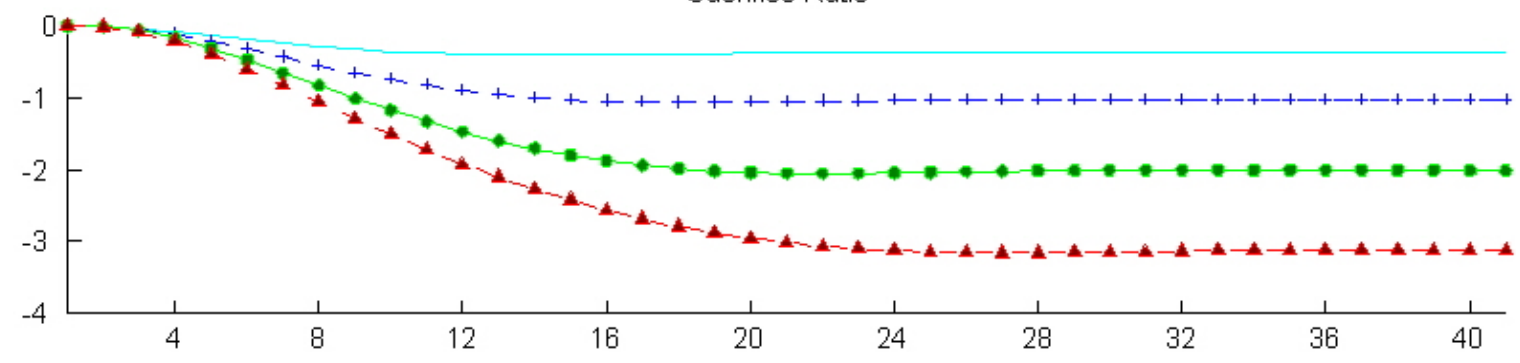


Figure 3: Responses to Unfavorable and Favorable Supply Shocks (Positive Shock Circle; Negative Shock Triangle)
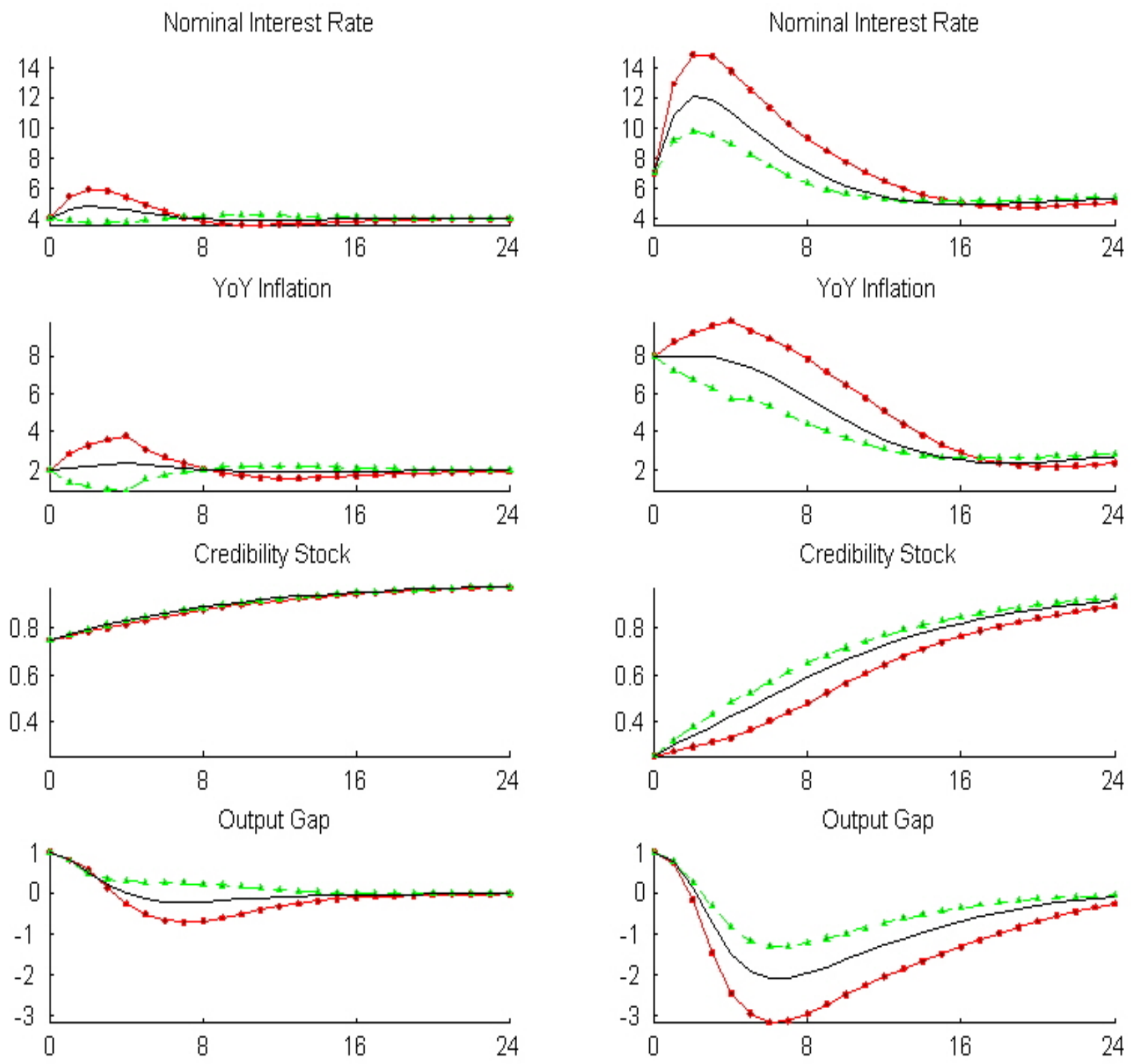

Advanced economy with anchored long-term inflation expectations

More vulnerable emerging-market economy without anchored long-term inflation expectations 
Figure 4: Responses to Positive and Negative Demand Shocks (Positive Shock Circle; Negative Shock Triangle)
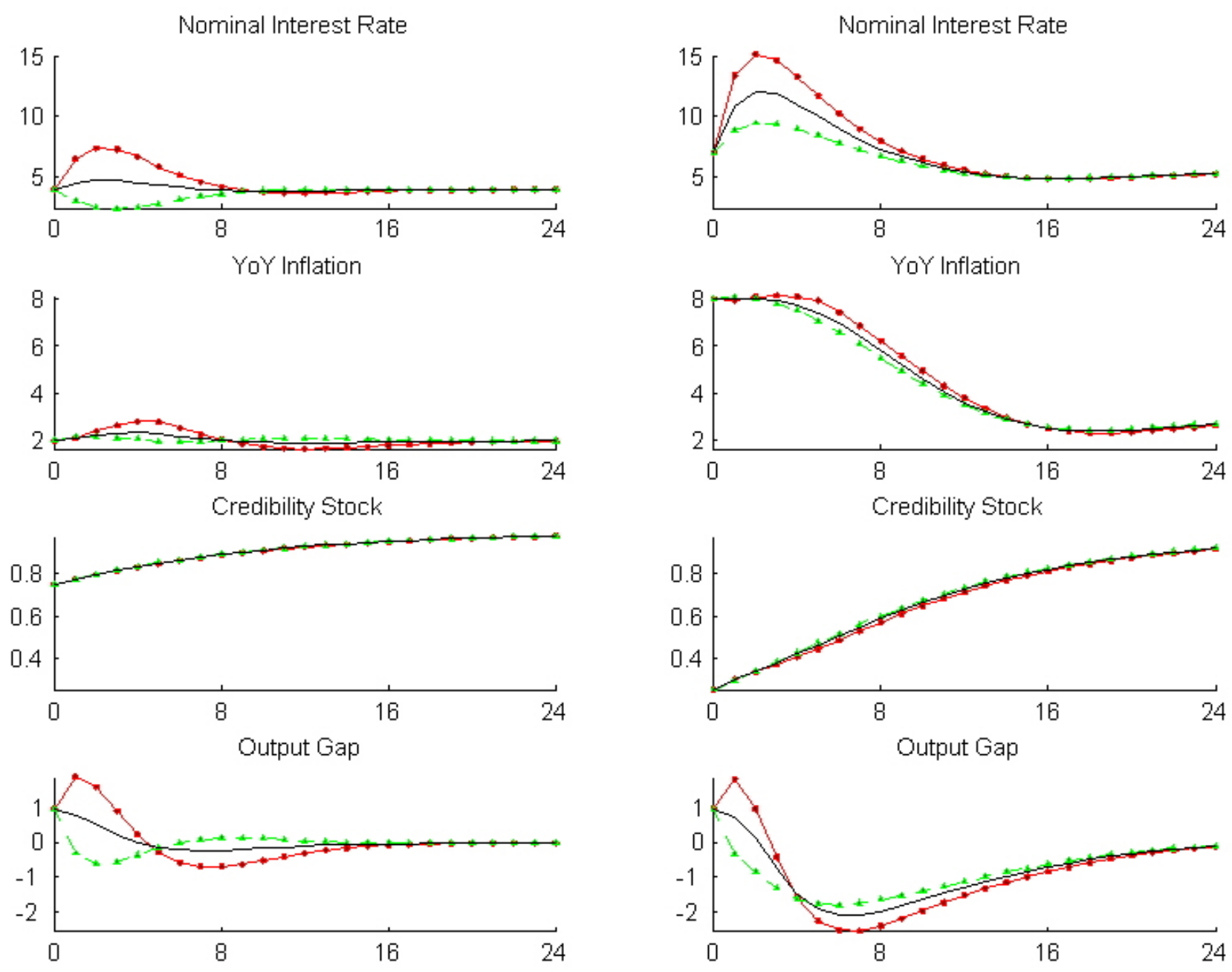

Advanced economy with anchored long-term inflation expectations

More vulnerable emerging-market economy without anchored long-term inflation expectations 
Figure 5: Cost of Delaying Interest Rate Hikes in Response to an Unfavorable Supply Shock in an Vulnerable Emerging-Market Economy with High Inflation and Low Initial Credibility (No Delay Triangle; Delay Circle)
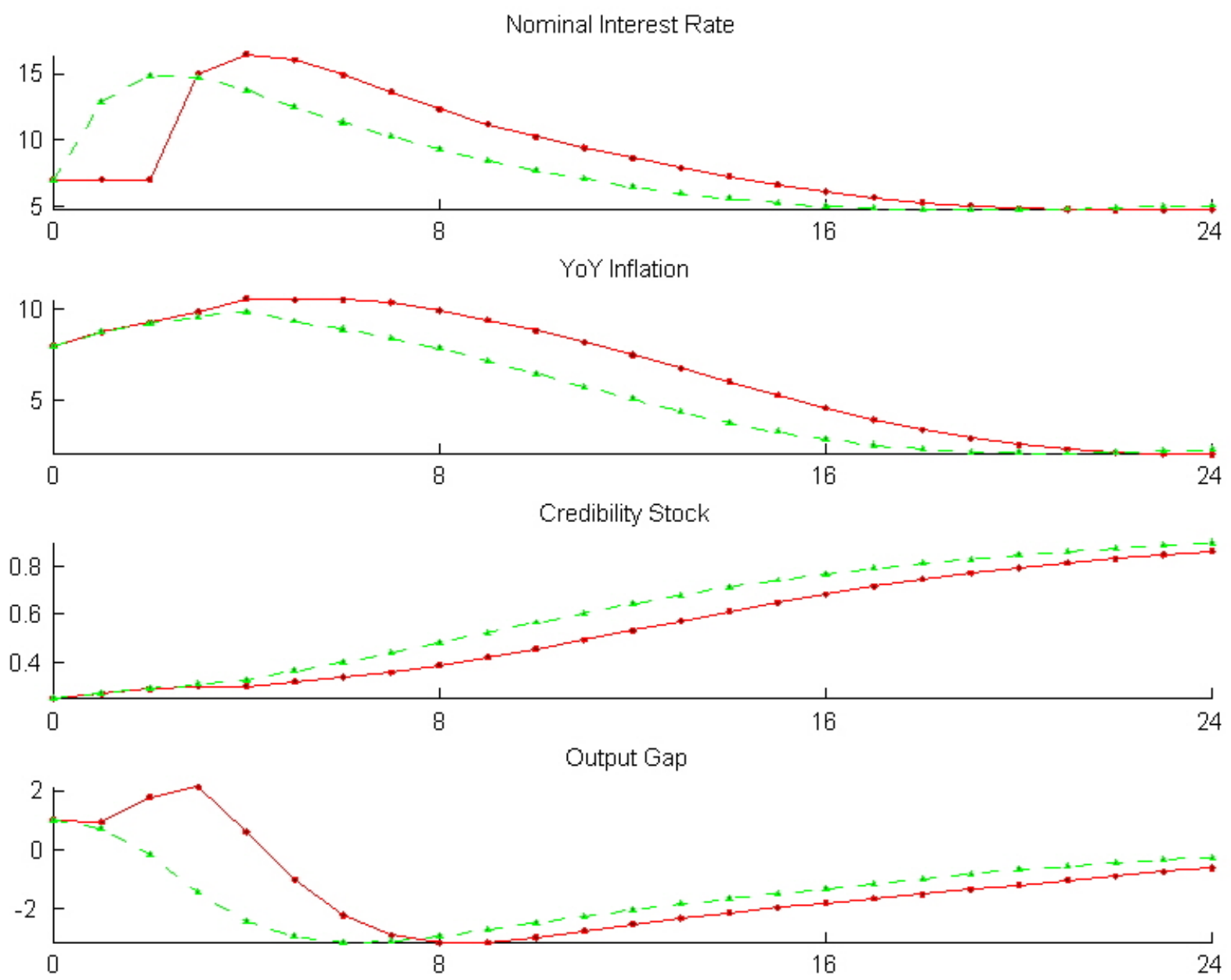